Bangl. J. Vet. Med. (2009). 7(2) : $348-352$

\title{
CLINICAL EVALUATION OF DIFFERENT TREATMENT REGIMES FOR MANAGEMENT OF MYIASIS IN CATTLE
}

\author{
M. A. Rahman, M. A. Hossain and M. R. Alam* \\ Department of Surgery and Obstetrics, Faculty of Veterinary Science, Bangladesh Agricultural University, \\ Mymensingh-2202, Bangladesh
}

\begin{abstract}
Therapeutic effects of three different treatment regimes on the healing of myiasis wound in cattle were evaluated in the present study. The study was conducted in 15 myiasis affected cattle brought to the Veterinary Clinic, Bangladesh Agricultural University, Mymensingh. Dressing with oil of turpentine on alternate days and intramuscular administration of combined penicillin (procaine penicillin 300000 units and benzyl penicillin sodium 100000 units $/ 50 \mathrm{~kg}$ body weight) and streptomycin ( $0.5 \mathrm{~g} / 50 \mathrm{~kg}$ body weight) daily for 7 days resulted healing of 96\% wound depth and $94 \%$ wound area. Another treatment regime consisted of subcutaneous administration of ivermectin $(0.2 \mathrm{mg} / \mathrm{kg}$ body weight $)$ and combined penicillin and streptomycin daily for 7 days which produced recovery of $94 \%$ wound depth and $90 \%$ wound area. In case of wound dressing with tincture of iodine on alternate days and parenteral administration of combined penicillin and streptomycin resulted in healing of $78 \%$ wound depth and 36\% wound area. Myiasis wounds were very prone to occur in the navel, vulva, scrotum and shoulder area. These wounds predominantly occur in the cattle of over 2 years. The females were more frequently affected than the males. The present study suggests that, local dressing of wound with oil of turpentine and intramuscular administration of combined penicillin and streptomycin may be practiced for the clinical management of myiasis in cattle.
\end{abstract}

Key words: Myiasis, cattle, treatment, healing

\section{INTRODUCTION}

Myiasis is a condition where open wounds are infested with larvae of diptera flies. These infestations may cause annoyance to animals and disruption of normal habits including feeding and resting. The condition may cause loss of milk, meat and wool production. Myiasis also affects the quality of hides (McKelvie et al., 1993). Oestridae affect livestock production causing abortion, reduced milk production, losses in weight and fertility, poor hide quality and an impairment of the host's immune system (Otranto et al., 2004). The most frequent host for myiasis are cattle (46.4\%) followed by dogs (15.3\%), humans (14.7\%), pigs (6\%), horses (4\%) and sheep (1\%) (Sergio et al., 2007). The prevalence of myiasis has been reported to be $37.4 \%$, the infection rate may, however, go up to $100 \%$ (Papadopoulos et al., 1997). Cattle frequently sustain different types of wounds and it appears from clinical impression that a good percentage of these wounds are complicated with maggot infestation. This problem in cattle is fairly common in the field condition particularly in the season of fly prevalence (John, 1999). The therapeutic approaches mainly comprise dressing of wound with tincture of iodine, oil of turpentine or other antibacterial or vermicide agents. However, to the best of our knowledge there has been no report on the clinical management of myiasis in Bangladesh. The present work was, therefore, undertaken to study the effect of various therapeutic regimes in the management of myiasis wound in cattle. Occurrence of myiasis in cattle with respect to age, sex, breed and predilection site was also studied.

\section{MATERIALS AND METHODS}

\section{Experimental animals}

Fifteen myiasis affected cattle (5 male and 10 female) of ages ranging from 6 months to 3 years brought to the Veterinary Clinic of Bangladesh Agricultural University during January- June 2007 were investigated in the present study.

*Corresponding author’s cell phone: 01714073953 and e-mail: alammr74@yahoo.com. 


\section{A. Rahman and others}

\section{Diagnosis of myiasis}

Diagnosis was made on the basis of wound history, close examination of wound, characteristic odour, brownish exudation from the wound and demonstration of maggots (Blood and Henderson, 1983).

\section{Treatment of myiasis}

The affected animal was restrained, the wound area was exposed and maggots were removed with sterile forceps. Three treatment regimes were employed as furnished in Table 1. Gauze dipped in oil of turpentine (Group A) or tincture of iodine (Group B) was allowed to remain in the wound pocket for 2 minutes. The maggots came out from the wound to the surface and were removed. After removal of the maggots the wound was dressed with either oil of turpentine or tincture of iodine. Dressing of wound on alternate day was continued until healing. The antibiotic injections (Streptopen ${ }^{\circledR}$ ) were also given at the dose rate of $0.5 \mathrm{~g} / 50 \mathrm{~kg}$ i.m. once daily for seven days. In case of group C only superficial maggots were removed with forceps and ivermectin (Vermic ${ }^{\circledR}$ ) was administered at the dose rate of $0.2 \mathrm{mg} / \mathrm{kg}$ s.c. single dose and Streptopen ${ }^{\circledR}$ injection (as in Group A and B) were given daily for 7 days.

Table 1. Experimental protocol

\begin{tabular}{|c|c|c|}
\hline Groups & No. of animals & Therapeutic regime \\
\hline A & 5 & $\begin{array}{l}\text { Oil of turpentine (used locally) and } * \text { Streptopen }^{\circledR} \text { (procaine penicillin } 300000 \\
\text { units, benzyl penicillin sodium } 100000 \text { units and streptomycin } 0.5 \mathrm{~g} \text { ) at the dose } \\
\text { rate of } 0.5 \mathrm{~g} / 50 \mathrm{~kg} \text { i.m. daily for } 7 \text { days. }\end{array}$ \\
\hline B & 5 & $\begin{array}{l}\text { Tincture of iodine (used locally) and Streptopen }{ }^{\circledR} \text { at the dose rate of } 0.5 \mathrm{~g} / 50 \mathrm{~kg} \\
\text { i.m. daily for } 7 \text { days. }\end{array}$ \\
\hline $\mathrm{C}$ & 5 & $\begin{array}{l}* * \text { Vermic }^{\circledR} \text { (Ivermectin) } 0.2 \mathrm{mg} / \mathrm{kg} \text { body weight s.c. and Streptopen }{ }^{\circledR} \text { at the dose } \\
\text { rate of } 0.5 \mathrm{~g} / 50 \mathrm{~kg} \text { i.m. daily for } 7 \text { days. }\end{array}$ \\
\hline
\end{tabular}

*Streptopen ${ }^{\circledR}$ (Renata Ltd., Bangladesh), **Vermic ${ }^{\circledR}$ (Techno Drugs, Bangladesh).

\section{Assessment of wound healing}

The progress in wound healing was determined on the basis of reduction of wound area and wound depth. The healing status was monitored on every alternate day from day 3 to day 17.

\section{Occurrence of myiasis}

Occurrence of myiasis with respect to age, sex, breed and anatomical location was studied in 15 affected cattle.

\section{RESULTS AND DISCUSSION}

\section{Effects on wound area}

Therapeutic effect of different treatment regimes on the healing of wound area in cattle is shown in Table 2 . In case of turpentine-Streptopen ${ }^{\circledR}$ group, 38\% wound area was healed up at day 7 and $94 \%$ at day 17 of therapy. In tincture of iodine-Streptopen ${ }^{\circledR}$ group, $9 \%$ wound area was healed at day 7 and $36 \%$ at day 17 . In case of Vermic ${ }^{\circledR}$ Streptopen ${ }^{\circledR}$ group, 36\% wound healing was obtained at day 7 . The healing process in this group continued to progress and $90 \%$ wound area was found to be healed at day 17.

Table 2. Effects of different treatment regimes on the healing of myiasis wound area in cattle

\begin{tabular}{|l|l|l|l|l|l|l|l|l|}
\hline \multirow{2}{*}{ Groups } & \multicolumn{6}{l}{ Progressive reduction of wound area at different days (\%) } \\
\cline { 2 - 9 } & Day 3 & Day 5 & Day 7 & Day 9 & Day 11 & Day 13 & Day 15 & Day 17 \\
\hline A (n =5) & 0 & 17.94 & 37.76 & 57.01 & 73.08 & 84.11 & 91.96 & 94.39 \\
\hline B $(\mathrm{n}=5)$ & 0 & 0 & 8.81 & 9.35 & 13.96 & 18.83 & 22.49 & 35.5 \\
\hline C $(\mathrm{n}=5)$ & 0 & 15.47 & 36.49 & 55.89 & 71.59 & 81.52 & 87.30 & 90.30 \\
\hline
\end{tabular}

A $=$ Oil of turpentine dressing + Streptopen $^{\circledR}, \quad B=$ Tr. of iodine dressing + Streptopen $^{\circledR}$ and C $=$ Vermic $^{\circledR}+$ Streptopen $^{\circledR}$. 


\section{Effects on wound depth}

Table 3 shows the effect of various treatments on wound depth. In turpentine-Streptopen ${ }^{\circledR}$ group, 35\% wound depth reduced at day 7 and $96 \%$ at day 17 of therapy. In case of tincture of iodine-Streptopen ${ }^{\circledR}$ group, $20 \%$ wound depth reduced at day 7 while $78 \%$ reduced at day 17. In Vermic ${ }^{\circledR}$ - Streptopen ${ }^{\circledR}$ group, 24\% wound depth reduced at day 7 and $94 \%$ at day 17 .

Table 3. Effects of different treatment regimes on the healing of wound depth in cattle

\begin{tabular}{|l|l|l|l|l|l|l|l|l|}
\hline \multirow{2}{*}{ Groups } & \multicolumn{6}{l|}{ Progressive healing of wound depth at different days (\%) } \\
\cline { 2 - 9 } & Day 3 & Day 5 & Day 7 & Day 9 & Day 11 & Day 13 & Day 15 & Day 17 \\
\hline A $(\mathrm{n}=5)$ & 0 & 14.52 & 35.48 & 61.29 & 77.82 & 87.90 & 91.94 & 95.97 \\
\hline B $(\mathrm{n}=5)$ & 0 & 8.33 & 20.37 & 32.41 & 47.22 & 62.96 & 71.30 & 77.78 \\
\hline C $(\mathrm{n}=5)$ & 0 & 10.20 & 24.49 & 43.54 & 61.22 & 76.19 & 88.78 & 94.22 \\
\hline
\end{tabular}

A $=$ Oil of turpentine dressing + Streptopen $^{\circledR}, \mathrm{B}=$ Tr. of iodine dressing + Streptopen $^{\circledR}, \mathrm{C}=$ Vermic $^{\circledR}+$ Streptopen $^{\circledR}$.

The therapeutic effect of three different treatment regimes on healing of myiasis wound in cattle was assessed on the basis of wound area and wound depth. The best result was obtained in group A where the wounds were treated with oil of turpentine dressing and administration of combined penicillin and streptomycin. The healing of wound in this group as regards wound area (94\%) and wound depth (96\%) was attained at day 17 of therapy. The efficacy of oil of turpentine in the treatment of maggot wound has been reported by Agarwal and Singh (1990). Application of oil of turpentine to the wound helps removing maggots from the wound. Oil of turpentine creates an anoxic condition in the wound pocket and as a result the maggots crawl out of the pocket within 3-5 minutes (Bowe et al., 1977). Oil of turpentine, on the other hand, enhances ceruloplasmin activity which is thought to inhibit inflammatory injury by its antioxidant property (DiSilvestro, 1989). Turpentine has been reported to cause sharp increase in plasma fibrinogen which might promote wound healing (Rapaport and Zivelin, 1976).

Penicillin and streptomycin were used in all the treatment groups to counteract the mixed microbial infection. Penicillin acts by inhibiting bacterial cell wall synthesis and streptomycin inhibits prokaryote protein synthesis by preventing the transition from initiation complex to chain-elongating ribosome and causes miscoding (Brander and Pugh, 1977).

The subcutaneous administration of ivermectin and simultaneous administration of combined penicillin and streptomycin also yielded good result where healing of wound (94\% wound depth and $90 \%$ wound area) occurred at day 17 of therapy. Ivermectin is a broad spectrum anthelmintic effective against both ectoparasites and endoparasites including the maggots (Howard and Smith, 1999). It is assumed that ivermectin blocks nerve impulses on the nerve ending through release of gamma amino butyric acid (GABA), linking to the receptors and causing palsy and death of the mature and immature parasites (Campbell, 1985). Sharma (1994) reported that ivermectin was effective in healing granulating wound without complication. A chemotherapeutic trial with ivermectin in yaks at the dose rate of $1 \mu \mathrm{g} / \mathrm{kg}$ s.c. in the neck region was sufficient to kill or stop development of larvae of Hypoderma spp. in naturally infected myiasis (Anon, 2000). Charbon and Pfister (1997) stated that the ivermectin "microdose" applied to young animals or dry cows affected with myiasis showed an efficacy in almost $100 \%$ cases.

The treatment of myiasis wound with tincture of iodine dressing and antibiotics was relatively less effective as compared to other treatment regime discussed above. Tincture of iodine is widely used to disinfect the skin before surgical operation as it can penetrate readily into the pores and crevices of the skin surface. This agent also possesses germicidal and irritant effects on the tissues but it has no larvicidal effect (Arthur and Evelyn, 1970).

\section{Occurrence of myiasis}

Occurrence of myiasis with respect to age, sex and breed is shown in Table 4. In the present study, out of 15 animals affected with myiasis, the highest occurrence (40\%) was found in the adult animals of over 2 years and the lowest (27\%) occurrence was found in the calves of below 6 months. These findings could not be compared due to paucity of similar information in the available literature. Adult animals, however, may sustain wounds more frequently than the young animals. Some of these wounds may afterwards be converted to myiasis. 


\section{A. Rahman and others}

The occurrence of myiasis in animals between 6 months and 2 years was 33\%. In the present study, 67\% and $33 \%$ of the myiasis affected cattle were female and male respectively and $53 \%$ of the affected cases were cross bred cattle. The occurrence of myiasis wound in local and cross bred were $47 \%$ and $53 \%$ respectively. Similar findings have been reported by Kara et al. (2005), who explained that infestation rate of wounds with fly larvae was lower in the native cattle than in the cross bred cattle.

Table 4. Effects of age, sex and breed on the occurrence of myiasis in cattle

\begin{tabular}{|l|l|l|l|l|l|l|}
\hline \multicolumn{2}{|l|}{ Age group } & \multicolumn{2}{l|}{ Sex } & \multicolumn{2}{l|}{ Breed } \\
\hline$<6$ months (\%) & 6 months-2 years (\%) & $>2$ years (\%) & Male (\%) & Female (\%) & Local (\%) & Cross (\%) \\
\hline $4(27)$ & $5(33)$ & $6(40)$ & $5(33)$ & $10(67)$ & $7(47)$ & $8(53)$ \\
\hline
\end{tabular}

The anatomical location of wounds affected with myiasis were navel area, vulva, thigh, udder, shoulder and between the claws. Similar findings have been reported by Kumar and Ruprah (1984). They explained that myiasis occurred in the navel area of newborn calves, vulvar region of recently calved cows and in wounds in between the claws. Of the 15 myiasis wounds 4 (27\%) occurred in the navel area, 3 (20\%) occurred in each of vulva and shoulder region and 2 (13\%) occurred in thigh and udder region. The highest occurrence of myiasis (27\%) was found in the navel area, followed by vulva and shoulder region (20\% in each case). Joseph et al. (1987) stated that navels of new borne calves after detachment from the umbilical cord remain raw which on slight provocation may be wounded. The flies lay eggs to these wounds and subsequently myiasis is produced. Laake et al. (1988) stated that the vulva and perineal region of cows having been traumatized during parturition appear to be common sites for maggot infestation.

It appears from the present study that treatment of myiasis wound with oil of turpentine dressing on alternate days and parenteral administration of combined penicillin and streptomycin for 7 days was the most effective in the field condition.

\section{REFERENCES}

1. Agarwal DC and Singh B (1990). Orbital myiasis-A case report. Indian Journal of Ophthalmology 38: 187-188.

2. Anon (2000). Lanzhou Veterinary Research Institute, Chinese Academy of Agricultural Sciences, Xujiaping 11, Lanzhou 730046, Gansu, PR China.

3. Arthur G and Evelyn F G (1970). Pharmacology and Therapeutics. $7^{\text {th }}$ edn., Henry Kimpton Ltd., USA. p. 695.

4. Blood DC and Henderson (1983). Veterinary Medicine. $6^{\text {th }}$ edn., Bailliere Tindal. $1^{\text {st }}$ Anne’s Road, Eastbourne, East Sussex BB 213 UN. pp. 807-808.

5. Bowe DL, Amaro TE, Sotolongo GF and Alonso BP (1977). Otic myiasis in a newborn caused by Caliphoridae larvae of genous Phaenicia. Revista Cubana De Medicina Tropical 29: 75-79.

6. Brander GC and Pugh DH (1977). Veterinary Applied Pharmacology and Therapeutics. $3^{\text {rd }}$ edn., ELBS and Bailllier Tindal, London. pp. 547-557.

7. Campbell WC (1985). Ivermectin: An update. Parasitology Today 1: 10-16.

8. Charbon JL and Pfister K (1997). Recent data on the treatment of bovine hypodermyiasis using metrifonate (Neguvon) and ivermectin (Ivomec) in microdoses. Schweiz Arch Tierheilkd 139 (12): 550-557.

9. DiSilvestro RA (1989). Effects of inflammation on copper antioxidant enzyme levels. Advanced efficacy of different insecticides in the treatment of cattle hypodermosis in north-eastern Algeria. Veterinary Research 29 (1): 21-29.

10. Howard JL and Smith RA (1999). Current Veterinary Therapy 4: Food Animal Practice. $4^{\text {th }}$ edn., WB. Saunders Company, USA. pp. 34-35.

11. John HK (1999). Screwworms: Be on the Lookout. Veterinary Medicine Extension, University of California, Davis Tulare CA 93274.

12. Joseph SA, Karunamoorthy G and Latitha CM (1987). A study on the incidence of myiasis in domestic animals of Tamil Nadu. Cheiron 16: 175-178.

13. Kara M, Arslan MO and Gicik Y (2005). The prevalence of bovine hypodermosis in Kars province, Turkey. Tropical Animal Health and Production 37 (8): 617-622.

14. Kumar R and Ruprah NS (1984). Incidence and etiology of cutaneous myiasis in domestic animals at Hissar. Indian Veterinary Journal 61: 918-921.

15. Laake EW, Cushing EC and Parish HE (1988). Biology of the primary screwworm fly, Cochliomyia americana, and a comparison of its stages with those of C. macellaria. USDA Technical Bulletin No. 500. p. 24. 
16. McKelvie L, Hamal K and Reynolds R (1993). Producer and consumer welfare effects of an invasion of screwworm fly in the Australian livestock sector. A BARE report to the Queensland Department of Primary Industries, Brisbane, Australia.

17. Otranto D, Traversa D and Giangaspero A (2004). Myiasis caused by Oestridae: serological and molecular diagnosis. Parasitologia 46 (1-2): 169-172.

18. Papadopoulos E, Himonas C and Boulard C (1997).The prevalence of bovine hypodermosis in Greece. Parasitologia 39 (4): 431-433.

19. Rapaport SI and Zivelin A (1976). Thrombosis and haemostasis. Journal of Economic Entomology 58: 373-374.

20. Sergio EB, José DE, Angel BC, Franklin C, Janina S, Sabina B and Enrique M (2007). Incidence of myiasis in Panama during the eradication of Cochliomyia hominivorax. Sección de Entomología Médica, Instituto Conmemorativo Gorgas de Estudios de la Salud, PO Box 0816-02593, Panamá.

21. Sharma TR (1994). Efficacy of ivermectin in the treatment maggot wounds in lions. Indian Veterinary Journal 54: 409410. 